PNL-10174

\title{
A Qualitative Evaluation of \\ Radionuclide Concentrations in \\ Hanford Site Wildlife, \\ 1983 Through 1992
}

T. M. Poston

A. T. Cooper

October 1994

Prepared for the U.S. Department of Energy under Contract DE-AC06-76RLO 1830

Pacific Northwest Laboratory

Operated for the U.S. Department of Energy by Battelle Memorial Institute 


\section{DISCLAIMER}

This report was prepared as an account of work sponsored by an agency of the United States Government. Neither the United States Government nor any agency thereof, nor Battelle Memorial Institute, nor any of their employees, makes any warranty, expressed or implied, or assumesany legal liability or responsibility for the accuracy, completeness, or usefulness of any information, apparatus, product, or processdisclosed, or represents that its use would not infringe privately owned rights. Reference herein to any specific commercial product, process, or service by trade name, trademark, manufacturer, or otherwise does not necessarily constitute or imply its endorsement, recommendation, or favoring by the United States Government or any agency thereof, or BattelleMemorial Institute. The views and opinions of authors expressed herein do not necessarily state or reflect those of the United States Government or any agency thereof.

PACIFIC NORTHWEST LABORATORY

operated by

BATTELLEMEMORIAL INSTITUTE

for the

UNITED STATES DEPARTMENT OF ENERGY

under Contract DE-AC06-76RLO 7830

Printed in the United States of America

Available to DOE and DOE contractors from the

Office of Scientific and Technical Information, P.O. Box 62, Oak Ridge, TN 371131; prices available from (615) 576-8401. FTS 626-8401.

Available to the public from the National Technical Information Service, U.S. Department of Commerce, 5285 Port Royal Rd., Springfield, VA 22161. 


\section{A Qualitative Evaluation of Radionuclide Concentrations in Hanford Site Wildlife, 1983 Through 1992}

T. M. Poston

A. T. Cooper

October 1994

Prepared for

The U.S. Department of Energy

under Contract DE-ACO6-76RLO 1830

Pacific Northwest Laboratory

Richland, Washington 99352 


\section{Summary}

Environmental monitoring has been conducted at the U.S. Department of Energy's (DOE's) Hanford Site in southeastern Washington State since 1945. Fish and wildlife have been monitored since 1945, however, a major emphasis on mammals did not occur until the 1970s. This report focuses on the 10-year period from 1983 through 1992 . The objectives of this report are to evaluate ${ }^{90} \mathrm{Sr}$ and ${ }^{137} \mathrm{Cs}$ concentrations in Site wildlife populations and, when possible, evaluate trends in concentrations over this period of time.

No distinct trends in radionuclide concentrations were apparent in most species sampled. Many measurements were at or below the analytical limit of detection. This evaluation found that concentrations of ${ }^{90} \mathrm{Sr}$ in rabbit and deer bone were elevated in animals collected from areas adjacent to industrialized areas. Similarly, radionuclide concentrations in duck muscle from waterfowl collected at B Pond were elevated with ${ }^{137} \mathrm{Cs}$ when compared to background concentrations. None of the measured concentrations were high enough to pose any risk to theoretical human consumers of game animals inhabiting the Hanford Site. Estimates of the annual dose from the consumption of $40 \mathrm{~kg}$ (88 lb) of Hanford Site wildlife were less than 0.001 times the National Council on Radiation Protection and Measurements and the DOE guideline of $100 \mathrm{mrem} / \mathrm{yr}$. 


\section{Acknowledgments}

The authors express their appreciation to R. W. Hanf, Jr., R. L. Dirkes, and J. A. Fall for critical reviews of this report, and to M. K. DeSmet for editorial assistance. Wildlife samples were collected by numerous Radiation Protection Technologists over the study period. 


\section{Contents}

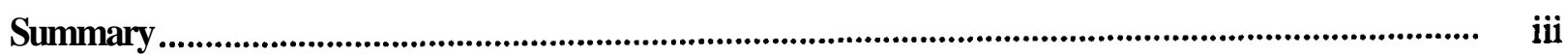

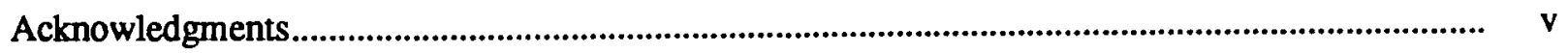

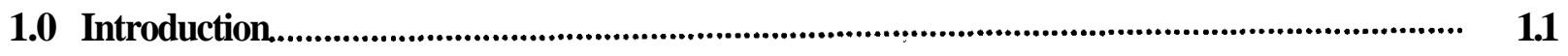

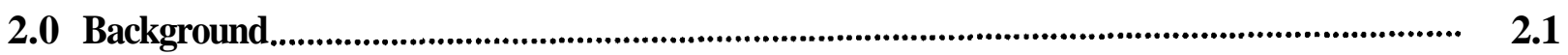

2.1 Aquatic Waste Sites..................................................................................................... 2.2

2.2 Terrestrial Sites

3.0 Sampling and Analysis ......................................................................................

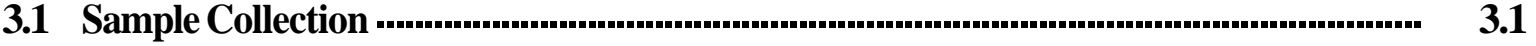

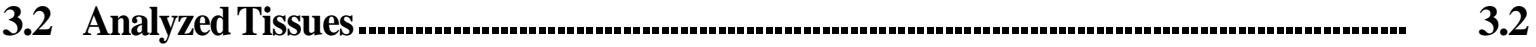

3.3 Radiochemical Analyses ................................................................................

3.4 Data Evaluation .............................................................................................................. 3.2

4.0 Results...........................................................................................................................

4.1 Deer ..............................................................................................................

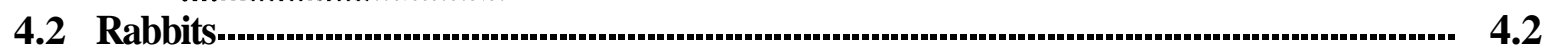

4.3 Ducks.................................................................................................................. 4.2

4.4 Upland Game Birds ........................................................................................................ 4.6

5.0 Discussion..................................................................................................... 5.1

5.1 Offsite Movement of Wildlife and Potential Public Exposure............................................. 5.1

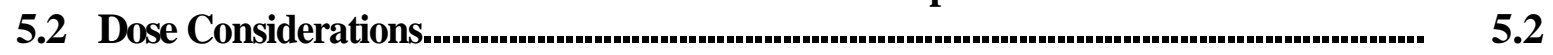

6.0 Conclusions.......................................................................................................................

7.0 References........................................................................................................................... 7.1 


\section{Figures}

2.1 Sampling Locations for Wildlife and Locations of Selected Low-Level Waste Sites ............... 2.3

3.1 Example Box Plot of Tissue Concentrations on a Log Scale ......................................... 3.4

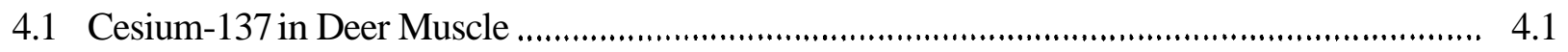

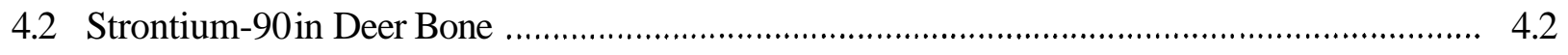

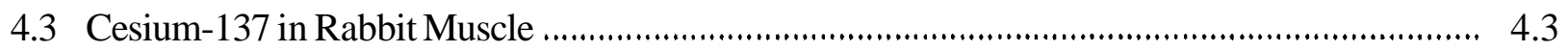

4.4 Strontium-90in Rabbit Bone ........................................................................................... 4.4

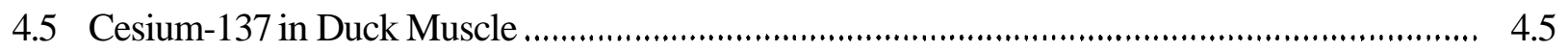

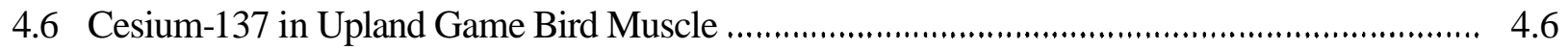

\section{Tables}

3.1 Maximum Number of Onsite Locations Scheduled for Routine Monitoring of Wildlife .......... 3.3

5.1 Fifty-YearEffective Dose Equivalent Resulting fram the Consumption of Wildlife Muscle Collected in 1992 


\subsection{Introduction}

The U.S. Department of Energy's (DOE's) Hanford Site was established in 1943 in southeastern Washington State for nuclear materials production. Although the Site is quite large $\left(1450 \mathrm{~km}^{2}\right.$ [560 $\left.\mathrm{mi}^{2}\right]$ ), only about $6 \%$ of the Site has been developed for industrial purposes (Woodruff et al. 1993). The majority of land supports a wide variety of wildlife. Wildlife has been monitored on the Site as a biological resource, i.e., population studies, and for exposure to radioactive materials. A report on radionuclide concentrationsin fish was published in 1994 (Poston 1994). Monitoring for radioactivity has been performed on a number of mammalian and avian species; however, recent efforts have focused on species that are of public interest. Specifically, rabbits, deer, ducks, and upland game birds, including pheasant (Phasianus colchicus) and chukar (Alectoris graeca), have been collected on a routine basis. This sampling has generally targeted areas close to Site facilities, waste management areas, and the Columbia River. In the past 4 years, background locations have been identified and sampled to provide an indication of Site impacts on wildlife by comparing tissue concentrations of radionuclides.

The data used in this study were collected during routine monitoring of the Hanford Site. The objectives of wildlife monitoring efforts were:

- to evaluate radionuclide concentrations in wildlife and potential influence on environmental dose to human populations

- to evaluate contaminant data for indications that wildlife may have intruded into waste management areas on the Site

- to determine and quantify the concentrations of radionuclides in wildlife for public assurance

- to provide baseline data to quantify incremental effects that could result from unexpected releases of radioactive materials onsite.

The objectives of this report are to evaluate the concentrations of radionuclides in Site wildlife populations and, when possible, qualitativelyevaluate trends. The report specifically addresses ${ }^{90} \mathrm{Sr}$ and ${ }^{137} \mathrm{Cs}$ in selected wildlife tissues because other radionuclides have not accumulated in wildlife at measurable quantities. Bone samples were analyzed for ${ }^{90} \mathrm{Sr}$ because $\mathrm{Sr}$ is a chemical analog to $\mathrm{Ca}$ (a major constituent of bone) and its uptake and distribution in bone is similar to $\mathrm{Ca}$ (Coughtrey and Thome 1983). Because ${ }^{90} \mathrm{Sr}$ is incorporated into bone, it is retained for extended periods of time and it has a much longer biological half-life than ${ }^{137}$ Cs (i.e., 100 to 700 days in laboratory animals [DiGregorio et al. 19771). Cesium-137 was evaluated in muscle because ${ }^{137} \mathrm{Cs}$ is a chemical analog of $\mathrm{K}$, it accumulates in muscle tissue which is naturally high in $\mathrm{K}$, and is a concem for potential dose to consumers of meat (Eisenbud 1987). The biological half-life of ${ }^{137} \mathrm{Cs}$ in laboratory animals is 3 to 40 days (DiGregorio et al. 1977), hence ${ }^{137} \mathrm{Cs}$ more rapidly depurates from animal tissue than ${ }^{90} \mathrm{Sr}$ and the long term dose to wildlife is lower. The radiochemical analyses used to monitor radionuclides in wildlife are extremely sensitive and past monitoring has documented contamination in a variety of Site wildlife. As a point of reference, concentrations of ${ }^{90} \mathrm{Sr}$ and ${ }^{137} \mathrm{Cs}$ are compared to pre-1983 concentrationsthat may represent some of the highest concentrations of ${ }^{90} \mathrm{Sr}$ and ${ }^{137} \mathrm{Cs}$ in wildlife that could have been harvested on and around the Hanford Site. 


\subsection{Background}

Wildlife sampling has been conducted on the Hanford Site since 1945; however, primary emphasis in early years was on monitoring fish from the Columbia River. Historical releases of radioactive materials to the Columbia River and accumulation of radionuclides in Columbia River fish have been reviewed by Walters et al. (1992), Denham et al. (1993), Heeb and Bates (1994), and Poston (1994). Because ducks were hunted in the Columbia Basin and ducks resided on the Hanford Reach (which received reactor cooling water) or low-level waste-waterdisposal ponds located on the Site, a major emphasis was also placed on waterfowl monitoring (Hanf et al. 1992). Early monitoring studies included holding ducks in pens on the river to determine the accumulation of radionuclides from reactoreffluents (Hanf et al. 1992). Subsequent studies and monitoring efforts included collection of samples from local hunters and onsite monitoring studies. Expansion of monitoring efforts to include other species of wildlife (small mammals, deer, upland game birds) did not get started until the mid- to late-1960s and the 1970s.

The movement of ducks from low-level waste-water disposal ponds to offsite locations was a concern expressed in the early years of the Site. Nineteen-sixty-four may be considered the year most likely to have the greatest probability of high concentrations of ${ }^{137} \mathrm{Cs}$ in duck muscle collected off Site. On June 11, 1964, about 10,000 Ci of fission products were accidentally discharged to Gable Mountain Pond and B Pond (Backman and Roddy 1965). Concentrations of ${ }^{137} \mathrm{Cs}$, which constituted only $0.33 \%$ of the release, accumulated in resident duck muscle collected from Gable Mountain Pond. Resident ducks sampled from Gable Mountain Pond within one month of the release contained from 8 to $180,000 \mathrm{pCi}$ ${ }^{137} \mathrm{Cs} / \mathrm{g}$ muscle. Muscle samples collected from September through November of 1964 contained 1 to $3,020 \mathrm{pCi}{ }^{137} \mathrm{Cs} / \mathrm{g}$ muscle.

Elevated ${ }^{137} \mathrm{Cs}$ in duck samples harvested from the Columbia River or nearby offsite ponds were an indication that the duck had resided on one of the low-level waste-water ponds on Site because the single pass reactor effluents that were discharged to the Columbia River rarely contained fission products (Heeb and Bates 1994). The maximum ${ }^{137}$ Cs concentration in duck muscle collected on the Hanford Reach of the Columbia River in 1964 was 440 pCi/g; the next highest concentration was 14 pCi/g (Foster et al. 1965). Only 13 of 98 duck samples collected had concentrations greater than the 1964 minimum detectable concentration(MDC [0.7 pCi/g]). Duck samples were also submitted by local hunters for analysis. None of these additional 71 samples submitted by local hunters in 1964 contained measurable amounts of ${ }^{137} \mathrm{Cs}$ above the MDC (Foster et al. 1965). The influx of migratory waterfowl into the Columbia Basin greatly reduces the probability of a hunter hawesting a contaminated resident duck that had previously resided on a low-level waste pond. Moreover, resident ducks tend to remain on the lowlevel waste-water ponds, a conclusion consistent with opinions of Site biologists at the time of the 1964 discharge to Gable Mountain Pond (Backman and Roddy 1965), and supported by monitoring results in 1964 and 1965 (Foster et al. 1965,1966).

The potential for radiological doses to humans arising from the consumption of ducks that once resided on Site is low. Early evaluations of local eating habits indicated that the likelihood of obtaining a dose from the consumption of fish or wildlife was much greater for fish than for waterfowl. It was recognized early on that migratory ducks that settled into the Columbia Basin during the fall hunting season greatly diluted the harvestable population of Site based ducks and that the probability of harvesting a Hanford Site duck was low.

When single pass reactors were operating from 1944 through 1971, aqueous effluents released to the Columbia River contained ${ }^{32} \mathrm{P}$ and ${ }^{65} \mathrm{Zn}$ which accumulated in muscle to levels 10 to 1000 times greater than levels of ${ }^{137} \mathbf{C s}$. For the current 1983 through 1992 study period, neither ${ }^{65} \mathbf{Z n}$ nor ${ }^{32} \mathbf{P}$ were 
found because they were no longer produced and their radiological half-lives were so short that they had essentially decayed to stable isotopes.

Radionuclide analysis also showed that deer residing near outdoor radiation zones tended to accumulate higher concentrations of ${ }^{90} \mathrm{Sr}$ and ${ }^{137} \mathrm{Cs}$ than groups of deer residing elsewhere on Site. Six deer residing within $2 \mathrm{~km}(1.2 \mathrm{mi})$ of radiation zones had a range of 0.20 to $3.43 \mathrm{pCi} / \mathrm{g}{ }^{137} \mathrm{Cs}$ and 5.3 to $65 \mathrm{pCi} / \mathrm{g}{ }^{90} \mathrm{Sr}$ in bone (Eberhardt et al. 1982). The "control" concentration ranges from 5 deer in onsite populations were as follows: 0.03 to $0.04 \mathrm{pCi} / \mathrm{g}$ for ${ }^{137} \mathrm{Cs}$ in muscle; 0.52 to $3.00 \mathrm{pCi} / \mathrm{g}$ for ${ }^{90} \mathrm{Sr}$ in bone. These results are probably the most representative data for Site deer collected immediately prior to the study period. Compared to earlier monitoring data, the Eberhardt et al. (1982) data were biased high because they were collected by design close to the 200 Area ponds, whereas earlier monitoring studies sampled the entire Hanford Site deer population. The ${ }^{137} \mathrm{Cs}$ results are also consistent with the early monitoring data for ${ }^{90} \mathrm{Sr}$ collected from 1983 through 1992 which also showed that deer bone collected from the 200 Areas and 100-N Area had higher concentrations of ${ }^{90} \mathrm{Sr}$ than bone in deer collected from locations not close to radiation zones. Eberhardt et al. (1982) also qualified the concentrations of ${ }^{137} \mathrm{Cs}$ observed in deer collected in 1979 through 1982 as slightly lower than deer sampled in the 1960s and 1970s to characterize the concentrations attributableto exposure to nuclear weapons testing fallout. The maximum concentration for deer muscle cited by Eberhardt et al. (1982) was $51.3 \mathrm{pCi}{ }^{137} \mathrm{Cs} / \mathrm{g}$.

For the study period of 1983 through 1992, collection of deer, rabbits, ducks, and upland game birds was conducted on a routine schedule. Sampling locations were selected primarily to monitor contamination in wildlife residing near operating facilities. Collection of wildlife from offsite locations occurred very infrequently in the early years, and a routine background sampling program was not instituted until 1990.

A better understanding of the current state of radiological impacts on Hanford wildlife can be attained by knowledge of past practices and discharges at the Hanford Site. This section provides a brief overview of past practices and how they have influenced exposure of Hanford wildlife to Site effluents and waste management areas with emphasis on the 1983-1992 period. Wildlife may accumulate radionuclides from drinking contaminated water, consuming contaminated animals or plants, or inhaling atmospheric contamination. The presence of contamination in fecal material may indicate ingestion of radioactive material from cribs by licking contaminated salt deposits, as was the case in the B-CCrib area (O'Farrell et al. 1973), or from eating plants whose roots have penetrated into low-level waste cribs as was the case in 1975 at the 216-A-24 Crib (Klepper et al. 1979). These early studies identified the concern of intrusion into low level waste areas and spawned the development of biobarrier technologies that have efficaciously controlled the problem.

Waste disposal areas on the Site are generally located adjacent to developed industrial areas (Figure 2.1). Waste disposal areas provide one of the most significant vectors of exposure to wildlife. These areas include surface water in the form of low-level waste-water disposal ponds that wildlife could use as a source of drinking water, burial grounds into which burrowing animals may intrude, or areas of lowlevel surface contamination. Many of these sites have been decommissioned and are presently scheduled for clean-up.

\subsection{Aquatic Waste Sites}

Key low-level aquatic waste sites were characterized in the late 1970s (Emery and McShane 1978). The 100-NTrench (1301-N) contained the highest levels of radionuclide contamination of any of the Site waste-water disposal facilities; however, access by ducks and larger species of wildlife was physically 


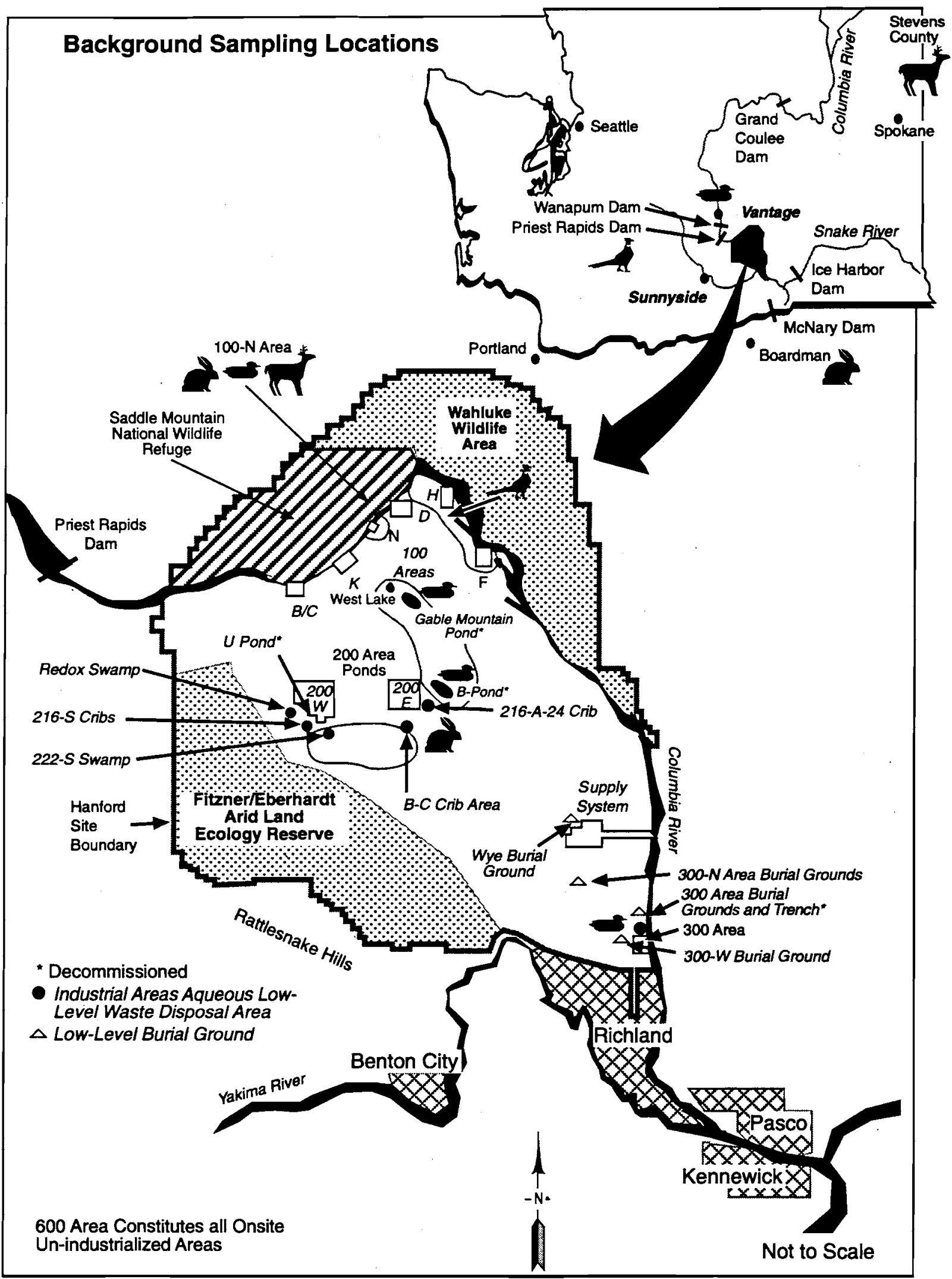

S9409007.1

Figure 2.1. Sampling Locations for Wildlife and Locations of Selected Low-Level Waste Sites 
restricted by placement of a large, heavy mesh screen over the trench. The screen was replaced with solid concrete covers in 1982 that eliminated access by wildlife. A second crib and trench (1325-N-3) was constructed in 1985 as a replacement for 1301-N and was also capped.

Gable Mountain Pond and B Pond (see Figure 2.1), with their associated trenches (B-3 and A-29, respectively), were the major sources of surface water around the 200 Areas that could be used by wildlife. These low-level waste-water disposal ponds supported a rich assemblage of waterfowl that consisted of resident populations as well as migrating birds in the fall and early winter (Fitzner and Rickard 1975). Gable Mountain Pond was drained, covered with fill, and decommissioned over 4 years from 1984 to 1988. A third pond, West Lake, located to the northwest of the Gable Mountain Pond site, was formed by the elevation of the ground-water table as a result of increased ground-waterdischarges of waste water in the 200 Areas. The pond is extremely saline (Poston et al. 1991) and was probably not used as a primary watering site by deer, nor was it used much by waterfowl because of its small size.

U Pond, a 5.7-ha (14-acre) waste-water pond, was located within the 200 West Area fence. U Pond was formed by discharges from a laundry facility, evaporator-crystallizing facility, and plutonium processing facilities in the 200 West Area. Waterfowl, upland game birds, rabbits, and coyotes had access to U Pond and its associated trenches from its creation in 1944 to its decommissioning in 1985.

Wildlife may have also had access to contaminated ground-water seepage entering the Columbia River from shoreline seeps on the Benton County side of the Hanford Reach (McCormack and Carlile 1984; Dirkes 1990). Presently, when all routes of exposure to Hanford contaminants are considered, the most probable source of exposure to Site wildlife may arise from the consumption of shoreline vegetation which could have elevated concentrations of contaminants from growing in areas with contaminated seeps (Antonio et al. 1993).

\subsection{Terrestrial Sites}

Many of the terrestrial sites used for low-level waste disposal were located within the fenced boundaries of the 200 West and 200 East Areas. However, there were areas located outside of fenced property that have received low-level solid waste for burial, or contained cribs for the disposal of relatively small quantities of liquid waste (Rogers and Rickard 1977). These included:

- B-C Cribs, located south of the 200 East Area

- 216-A-24 Crib, located east of 200 East area and south of B Pond

- 300 Area Burial grounds, located north and west of the 300 Area

Redox Pond (actually a swamp) and Cribs, located southwest of 200 West Area

- Wye Burial grounds.

Additionally, there are 28 low-level waste burial sites associated with the 100 Areas (Miller and Whalen 1987). The predominant radionuclides in these waste sites were ${ }^{60} \mathrm{Co}\left(\mathrm{T}_{1 / 2}=5.2 \mathrm{y}\right){ }^{(\mathrm{a})}$ and ${ }^{63} \mathrm{Ni}$ $\left(\mathrm{T}_{1 / 2}=92 \mathrm{y}\right)$, $^{(\mathbf{a})}$ which are activation products associated with steel waste (i.e., pipe, scrape). These radionuclides are not environmentally mobile nor biologically available for uptake.

(a) Radiologicalhalf-life. 


\subsection{Sampling and Analysis}

The methods used to collect and prepare wildlife samples and conduct radiochemical analyses are discussed below.

\subsection{Sample Collection}

This report evaluates radionuclide levels in rabbits, deer, upland game birds, and ducks collected from the Hanford Site and selected background locations (see Figure 2.1) from 1983 through 1992. The Site is comprised of numerically defined areas, e.g., the 100 Areas (reactor sites), 200 Areas (fuel separations and processing), and 300 Areas (research), undefined areas are designated as the 600 Area. Collection of wildlife, while scheduled on a routine basis at specific locations, is generally opportunistic because wildlife populations fluctuate both seasonally and on an annual basis based on population dynamics. Population fluctuations are influenced by climate, disease, predation, and natural cycles. Consequently, in some years, not all scheduled samples were obtained. The extensive nature of the wildlife sampling program compensates for the uncertainties inherent with wildlife sampling.

\subsubsection{Deer}

Mule deer (Odocoileus hemionus) were opportunistically sampled as road kills and in certain years were hunted from selected areas. Site collections were exclusively mule deer, although there have been sightings of white-tailed deer (0. virginians) on the Hanford Site north of the Columbia River. Two offsite background samples were collected in 1992 from Stevens County in northeastern Washington State.

\subsubsection{Rabbits}

Rabbit collections consisted of both Nuttall's cottontail (Sylvilagus nutallii) and black-tailed jackrabbits (Lepus californicus). Cottontails were usually collected from the 300 Area and 100-N Area and jackrabbits were collected from the 200 Area locations. In 1990, both jackrabbits and cottontails were collected from Boardman, Oregon, a background location. Rabbits were collected by hunting and live trapping. Cottontail and jackrabbit data were combined for evaluation in this report.

\subsubsection{Upland Game Birds}

Upland game bird collections were predominantly ring-neck pheasants (Phasianus colchicus) collected from the area between 100-D and 100-F Areas. In the mid-1980s, some chukars were collected from the 200 West and 200 East sample collection areas (see Figure 2.1). No distinction was made between chukar and pheasant samples for the evaluations in this report. Game birds were primarily collected by hunting; however, some trapping has been attempted in recent years.

\subsubsection{Ducks}

Mallard (Anus platyrhynchos) was the target species for duck collections; however, other species have been collected including teal (Anus sp.), pintail (Anus acuta), and other dabbling ducks (Anus sp.) (see Landeen et al. 1992 and Fitzner and Rickard 1975 for a complete listing of birds reported on the Hanford Site). The most complete collection of ducks over the 10-year study period was at B Pond. 
Methods of collection included hunting and trapping. Collections were usually completed before migrating ducks entered the Columbia Basin.

\subsection{Analyzed Tissues}

Specific wildlife tissue samples analyzed included muscle, which was analyzed for gamma emitters (primarily ${ }^{137} \mathrm{Cs}$ ), bone, which was analyzed for ${ }^{90} \mathrm{Sr}$, and liver, which was analyzed for ${ }^{238} \mathrm{Pu}$ and 239,240 Pu (Table 3.1). In some species, liver and bone were not routinely analyzed (NRA) unless the measured concentration of ${ }^{137} \mathrm{Cs}$ in muscle exceeded $100 \mathrm{pCi} / \mathrm{g}$.

\subsection{Radiochemical Analyses}

Wildlife samples were analyzed by gamma spectroscopy for a large number of gamma-emitting radionuclides (Woodruff et al. 1993). Routinely, only ${ }^{7} \mathrm{Be},{ }^{40} \mathrm{~K}$, and ${ }^{137} \mathrm{Cs}$ were detected in wildlife muscle. Cobalt-60 was infrequently detected in the early 1980 s, but radiological decay and very small releases to the environment have reduced concentrations of ${ }^{60} \mathrm{Co}$ to undetectable levels in wildlife samples. Radiochemical methods were also used to measure ${ }^{90} \mathrm{Sr}$ in bone.

A7l results were reported as pCi/g wet weight. The MDCs on a wet-weight basis for ${ }^{90} \mathrm{Sr}$ and ${ }^{137} \mathrm{Cs}$ were 0.005 and $0.015 \mathrm{pCi} / \mathrm{g}$, respectively. The ${ }^{137} \mathrm{Cs} \mathrm{MDC}$ was adjusted to $0.02 \mathrm{pCi} / \mathrm{g}$ for samples analyzed in 1991 and 1992. The MDCs for other gamma-emitting radionuclides ranged from 0.02 to 0.2 $\mathrm{pCi} / \mathrm{g}$. These MDCs are contractual guidelines that the analytical facilities are obligated to meet by adjusting sample count time and aliquot size.

The analytical results reported herein were provided by two laboratories. Samples collected before June of 1990 were analyzed by U.S. Testing, Inc. (UST), Richland, Washington. Samples collected later in 1990, and 1991 and 1992, were analyzed by IT Analytical Services, Richland, Washington, which acquired the UST facilities in 1991. The analytical methods used for radiochemical analyses are summarized by Jaquish and Bryce (1990).

\subsection{Data Evaluation}

Data were graphically presented in scattergrams or, when enough samples were collected (i.e., four or more for each year), in box plots. Box plots show the 10th, 25th, 50th (median), 75th, and 90th percentiles for each year and sampling location as well as individual concentrations that lie above or below the $90 \%$ or $10 \%$ levels, respectively (Figure 3.1). Box plots were prepared on a log-scale because of the wide range of concentrations associated with wildlife data. Negative concentrations could not be presented on log-scale graphs, but are indicated when the box or 10th percentile line intersects the baseline of the figure. Median concentrations were reported instead of means because the median is not as radically influenced by outliers and may provide a more accurate estimate of the central tendency of environmental data when sample sizes are small (Jaquish and Bryce 1990). 
Table 3.1. Maximum Number of Onsite Locations Scheduled for Routine Monitoring of Wildlife

\begin{tabular}{|c|c|c|c|c|c|c|c|c|c|c|c|c|}
\hline \multirow[b]{2}{*}{ Species } & \multirow[b]{2}{*}{ Tissue } & \multirow[b]{2}{*}{ Radionuclide } & \multicolumn{10}{|c|}{ Year } \\
\hline & & & $\underline{1983}$ & $\underline{1984}$ & $\underline{1985}$ & $\underline{1986}$ & $\underline{1987}$ & $\underline{1988}$ & $\underline{1989}$ & $\underline{1990}$ & $\underline{1991}^{(a)}$ & $\underline{1992}$ \\
\hline \multirow[t]{3}{*}{ Cottontail } & Muscle & $\operatorname{Gamma}^{(b)}$ & $3(c)$ & 2 & 2 & 1 & 1 & 1 & 1 & 1 & 1 & 2 \\
\hline & Bone & ${ }^{90} \mathrm{Sr}$ & & 2 & 2 & 1 & 1 & 1 & 1 & 1 & 1 & 2 \\
\hline & Liver & ${ }^{238} \mathrm{Pu},{ }^{239,240} \mathrm{Pu}$ & & 2 & 2 & 1 & 1 & 1 & 1 & 1 & 1 & 2 \\
\hline \multirow[t]{3}{*}{ Jackrabbit } & Muscle & Gamma & 3 (c) & $2^{(d)}$ & 2 & 2 & 2 & 2 & 2 & 2 & 2 & 2 \\
\hline & Bone & ${ }^{90} \mathrm{Sr}$ & & 2 & 2 & 2 & 2 & 2 & 2 & 2 & 2 & 2 \\
\hline & Liver & ${ }^{238} \mathrm{Pu},{ }^{239,240} \mathrm{Pu}$ & & 2 & 2 & 2 & 2 & 2 & 2 & 2 & 2 & 2 \\
\hline \multirow[t]{3}{*}{ Mule Deer } & Muscle & Gamma & 6 & $7(e)$ & 7 & 7 & 7 & 7 & 7 & 7 & 7 & 7 \\
\hline & Bone(f) & ${ }^{90} \mathrm{Sr}$ & 6 & 1 & 1 & 1 & 1 & 1 & 1 & 1 & 2 & 2 \\
\hline & Liver & ${ }^{238} \mathrm{Pu},{ }^{239,240} \mathrm{Pu}$ & 6 & 7 & 7 & 7 & 7 & 7 & 7 & 7 & 7 & 7 \\
\hline \multirow[t]{3}{*}{ Game Birds } & Muscle & Gamma & $9(\mathrm{~g})$ & 5 & 5 & 5 & 5 & 5 & 5 & 5 & 5 & 5 \\
\hline & Bone & ${ }^{90} \mathrm{Sr}$ & -- & $5(\mathrm{NRA})^{(\mathrm{h})}$ & 5(NRA) & $5(\mathrm{NRA})$ & $5(\mathrm{NRA})$ & $5(\mathrm{NRA})$ & 5 (NRA) & $5(\mathrm{NRA})$ & 5(NRA) & 5 (NRA) \\
\hline & Liver & ${ }^{238} \mathrm{Pu},{ }^{239,240} \mathrm{Pu}$ & -- & $5(\mathrm{NRA})$ & 5 (NRA) & $5(\mathrm{NRA})$ & $5(\mathrm{NRA})$ & $5(\mathrm{NRA})$ & $5(\mathrm{NRA})$ & $5(\mathrm{NRA})$ & 5 (NRA) & 5 (NRA) \\
\hline \multirow[t]{3}{*}{ Ducks } & Muscle & Gamma & 6 & 5 & 5 & 4 & $4^{(i)}$ & 4 & 4 & 4 & 4 & 4 \\
\hline & Bone & ${ }^{90} \mathrm{Sr}$ & -- & $5(\mathrm{NRA})$ & $5(\mathrm{NRA})$ & $4(\mathrm{NRA})$ & 4(NRA) & $4(\mathrm{NRA})$ & $4(\mathrm{NRA})$ & $4(\mathrm{NRA})$ & $4(\mathrm{NRA})$ & 4(NRA) \\
\hline & Liver & ${ }^{238} \mathrm{Pu}, 239,240 \mathrm{Pu}$ & .• & $5(\mathrm{NRA})$ & $5(\mathrm{NRA})$ & $4(\mathrm{NRA})$ & $4(\mathrm{NRA})$ & $4(\mathrm{NRA})$ & 4(NRA) & $4($ NRA $)$ & $4(\mathrm{NRA})$ & 4 (NRA) \\
\hline
\end{tabular}

\footnotetext{
(a) First year background locations were documented in Bisping (1991); some background samples were collected in 1990, see text for listing of background locations.

(b) Includes ${ }^{137} \mathrm{Cs}$ and other gamma emitters.

(c) Only muscle samples were analyzed in 1983 and no distinction was indicated between cottontail and jackrabbit samples.

(d) First year that the 200 East and 200 West Areas were designated as separate sampling locations.

(e) In 1984, 6 roadkill deer (muscle and liver samples only) were identified implying a maximum of six onsite roadkill deer per year, the 200

Area ponds were the only identified onsite sampling location.

(f) Bone samples submitted from hunted deer only.

(g) Results were from cornposited samples of quail, pheasant, and chukar.

(h) Not routinely analyzed.

(i) West Lake substituted for Gable Mountain Pond (1987-1992) because Gable Mountain Pond was decommissioned in 1987.
} 


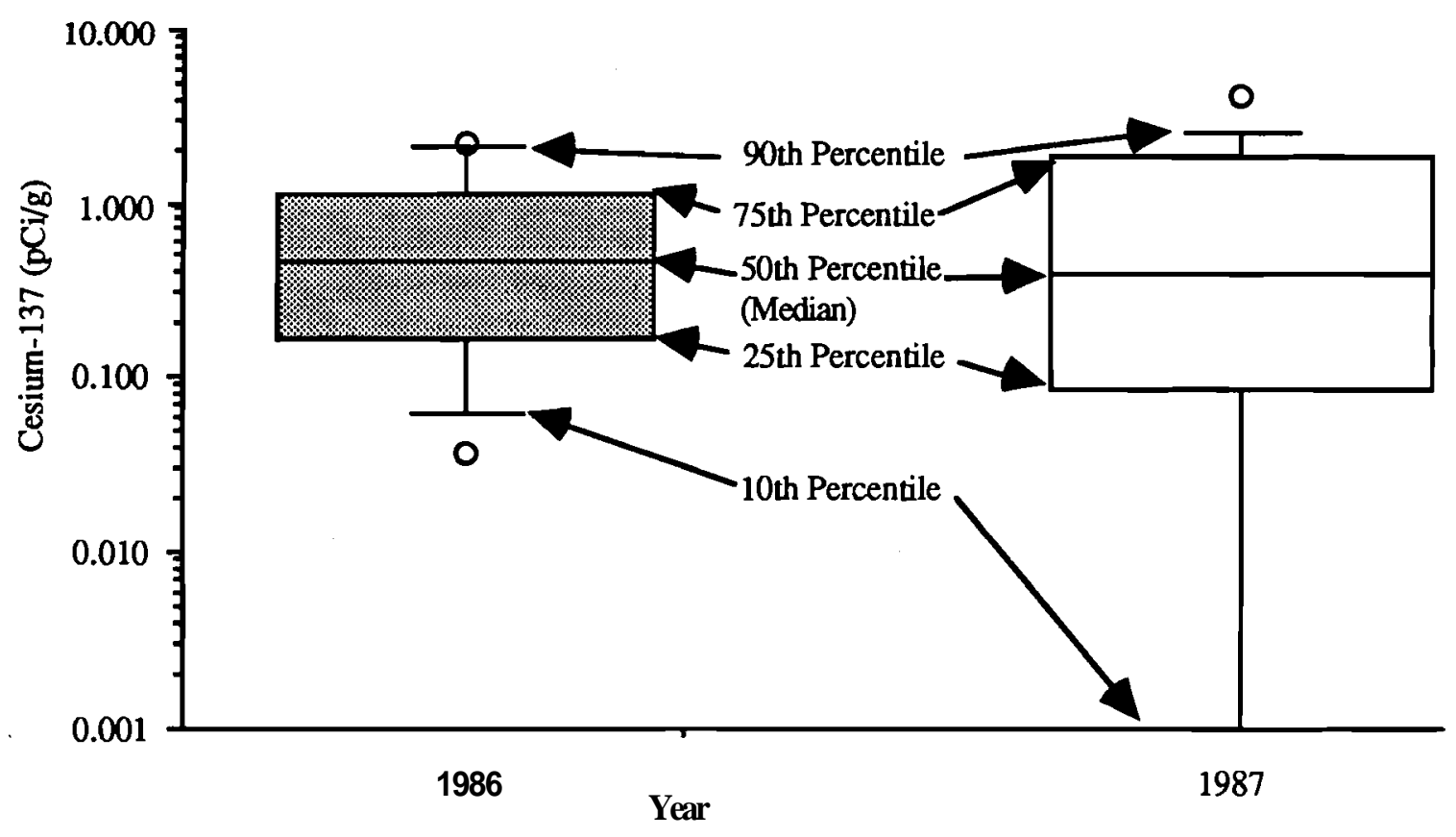

Figure 3.1. Example Box Plot of Tissue Concentrations on a Log Scale. Circles above or below the 90 th or 10 th percentile level are individual datum. 


\subsection{Results}

Contaminant trends were determined for ${ }^{137} \mathrm{Cs}$ and ${ }^{90} \mathrm{Sr}$ in wildlife samples collected on the Hanford Site from 1983 through 1992 . Data for ${ }^{238} \mathrm{Pu}$ and ${ }^{239,240} \mathrm{Pu}$ were generally less than detection $(<0.0004 \mathrm{pCi} / \mathrm{g})$ in deer and rabbit liver samples and are not addressed further in this report.

\subsection{Deer}

Fifty-three muscle samples were collected from Hanford Site deer during the study period and analyzed for gamma emitters. Two background samples were collected in 1992 from Stevens County about $250 \mathrm{~km}$ (156 mi) north-northeast of the Hanford Site (see Figure 2.1). Cesium-137 was the only man-made gamma emitter found in muscle samples. There was no clear contaminant trend apparent in the scattergrams and results were highly variable (Figure 4.1). Compared to the two samples collected from Stevens County, concentrations of ${ }^{137} \mathrm{Cs}$ in Hanford Site deer were not elevated and concentrations hovered near the limit of detection $(0.02 \mathrm{pCi} / \mathrm{g})$. The two highest onsite concentrations of ${ }^{137} \mathrm{Cs}$ occurred in the 200 Area in 1983 and 1985 (both <0.7 pCi/g) prior to the decommissioning of Gable Mountain Pond. All other ${ }^{137} \mathrm{Cs}$ concentrations measured in deer collected on Site were near or below the MDC level of $0.02 \mathrm{pCi} / \mathrm{g}$.

Seventeen bone samples from deer were analyzed for ${ }^{90} \mathrm{Sr}$ from 1983 through 1992 . Reported concentrations ranged from 0.009 to $68 \mathrm{pCi} / \mathrm{g}$ (Figure 4.2). No apparent contamination trends were evident because of the paucity of data. Concentrations of ${ }^{90} \mathrm{Sr}$ in some deer bone samples collected from the 100-N Area were clearly elevated relative to other samples collected on Site and the two background samples collected from Stevens County.

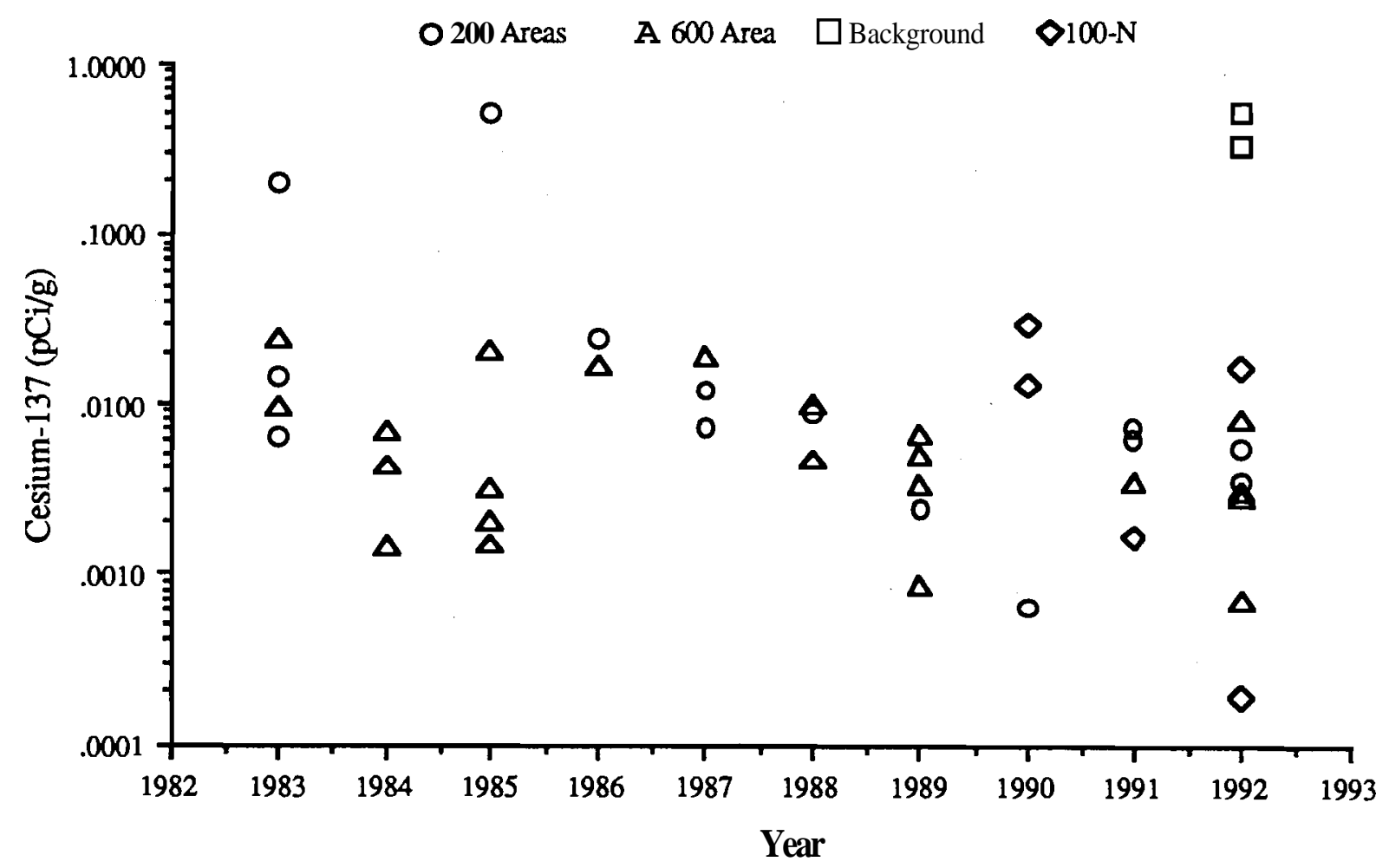

Figure 4.1. Cesium-137 in Deer Muscle 


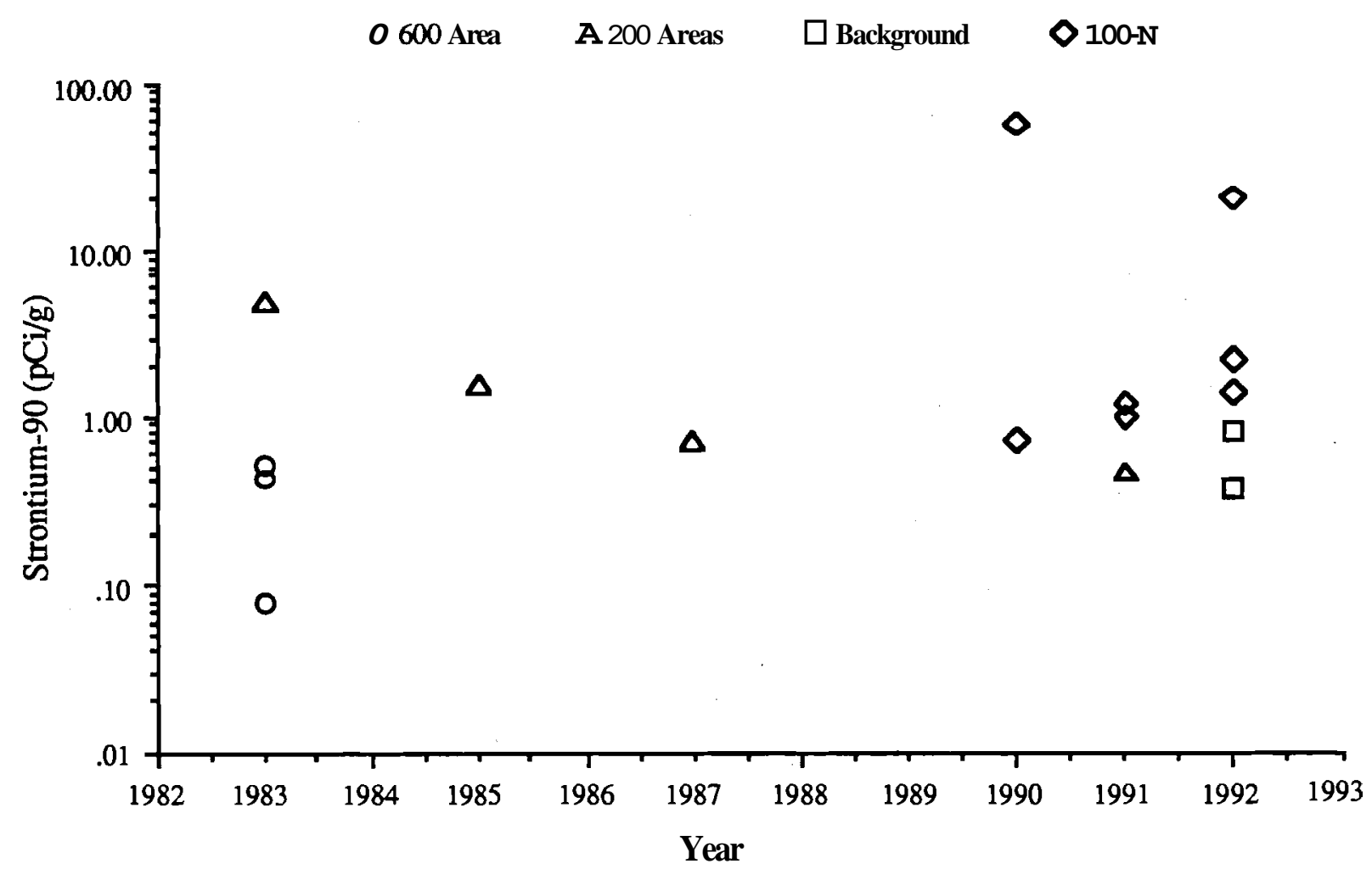

Figure 4.2. Strontium-90in Deer Bone

\subsection{Rabbits}

One-hundred eleven jackrabbits and cottontail rabbits were collected from the Hanford Site from 1983 through 1992 . The variability of ${ }^{137}$ Cs in muscle samples was high because the opportunities for rabbits to enter waste disposal areas were relatively high. Historically, concentrations of ${ }^{137} \mathrm{Cs}$ have ranged from below detection to $27 \mathrm{pCi} / \mathrm{g}$. There was no apparent trend in median muscle concentrations from 1983 through 1992 (Figure 4.3), nor was there any indication of any differences between locations.

Strontium-90 was readily measured in rabbit bone samples collected from 1983 through 1992 (Figure 4.4). Inspection of median ${ }^{90} \mathrm{Sr}$ concentrations in samples collected from the $100-\mathrm{N}$ Area indicates that higher concentrations were seen from 1987 through 1991 compared to levels reported in 1983 through 1985. Concentrations in 1992, however, were the lowest concentrations measured over the study period at 100-N Area and were comparable to concentrations measured in background populations from Boardman, Oregon, in 1990 (see Figure 2.1).

\subsection{Ducks}

Concentrations of ${ }^{137} \mathrm{Cs}$ in duck muscle samples collected from 1983 through 1992 indicate a general decline in median concentrations over the 10-year period (Figure 4.5). Most data were associated 


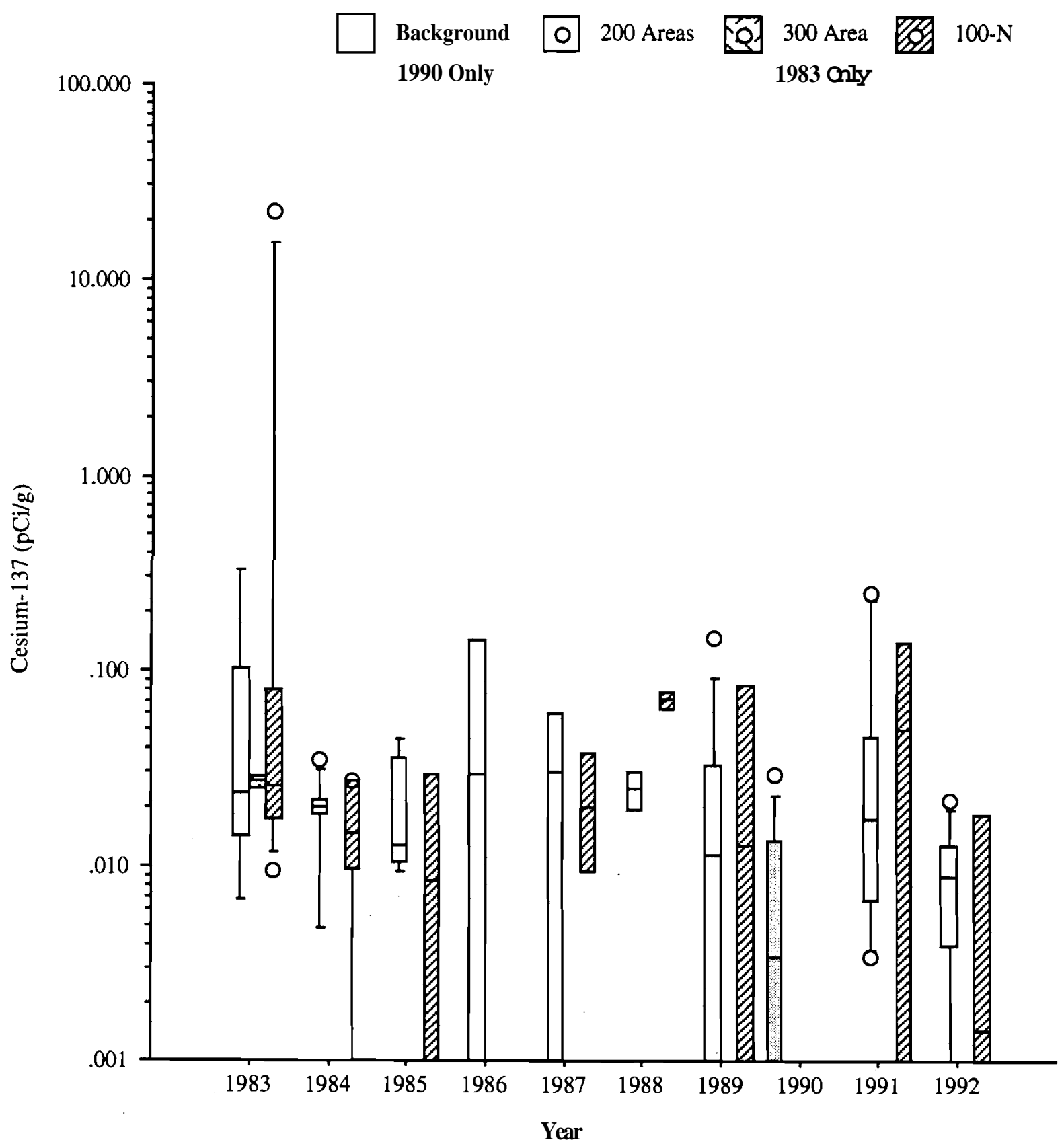

Figure 43. Cesium-137 in Rabbit Muscle 


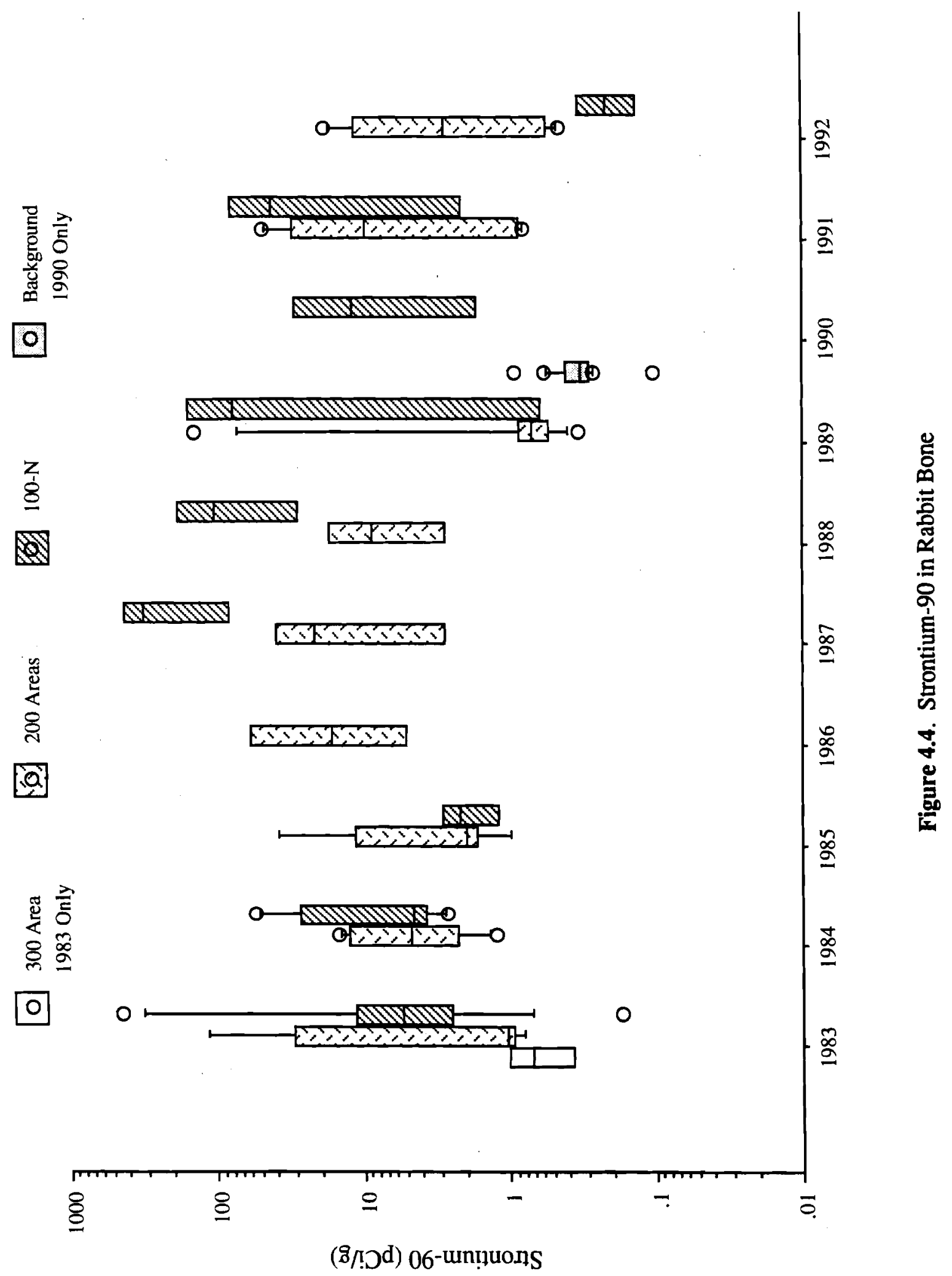



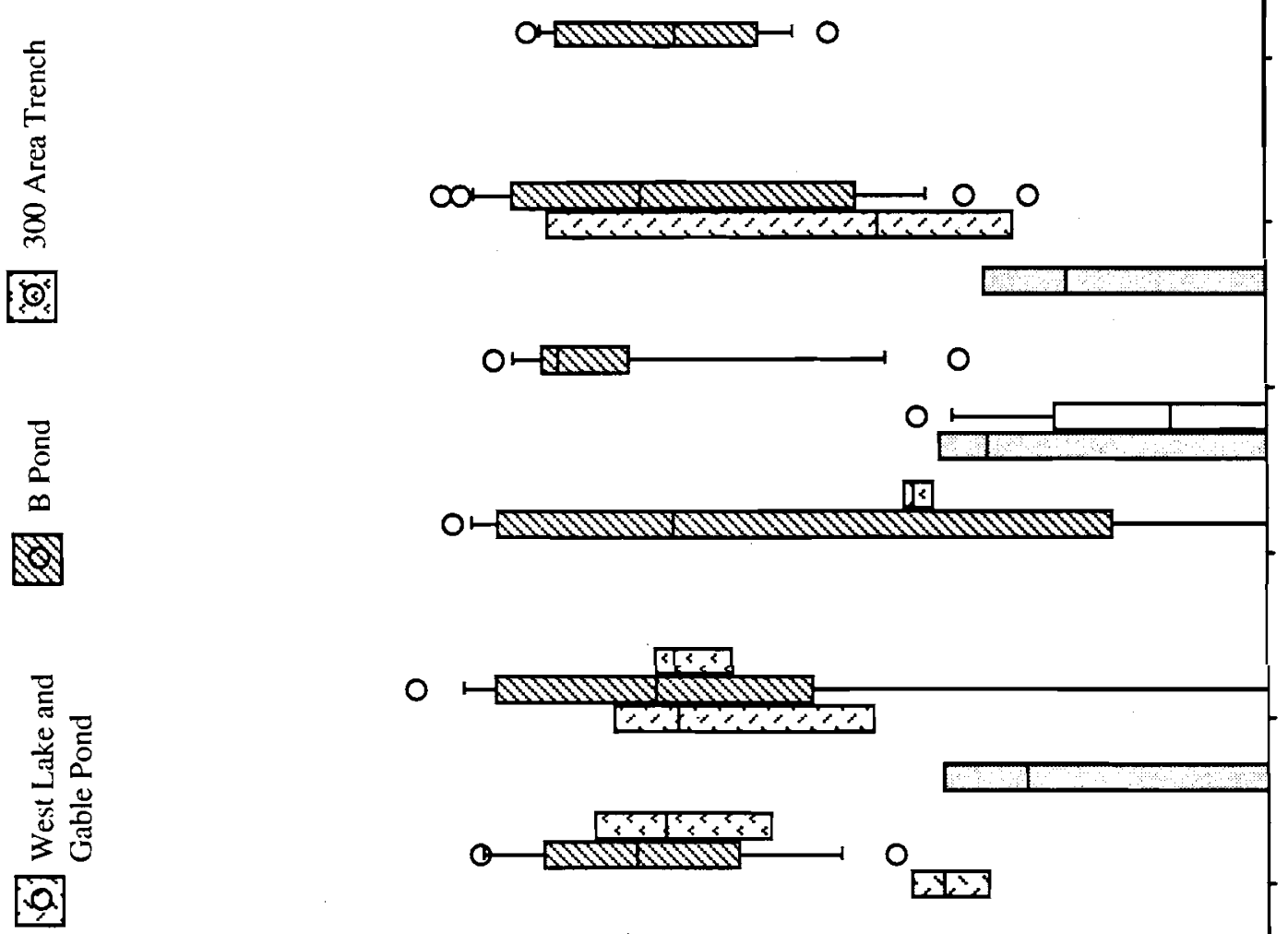

๙ั

g

号
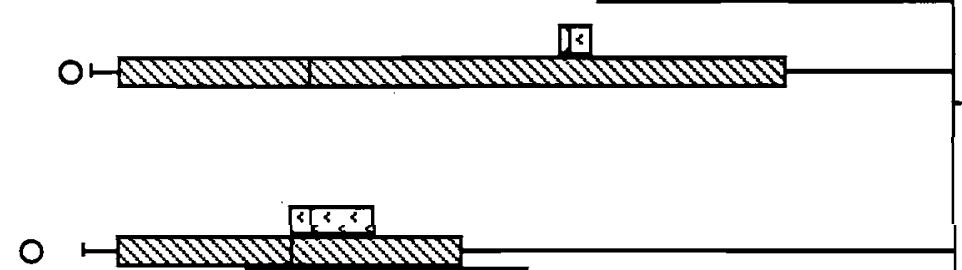

thy
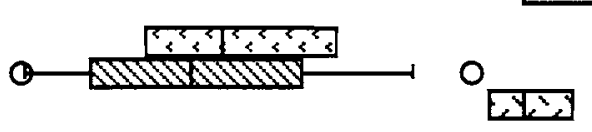

$\stackrel{\infty}{2}$

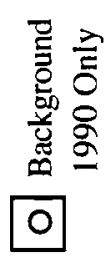
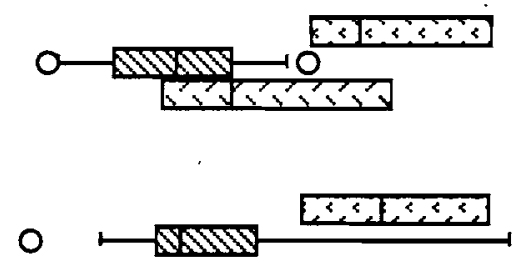

0

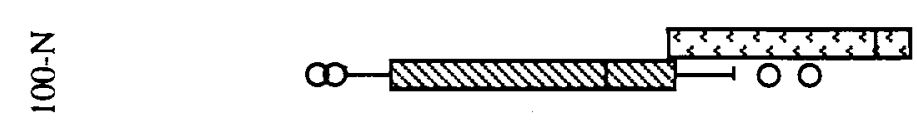

0

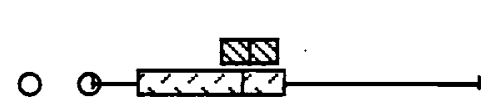

00

$\mathscr{\infty}$

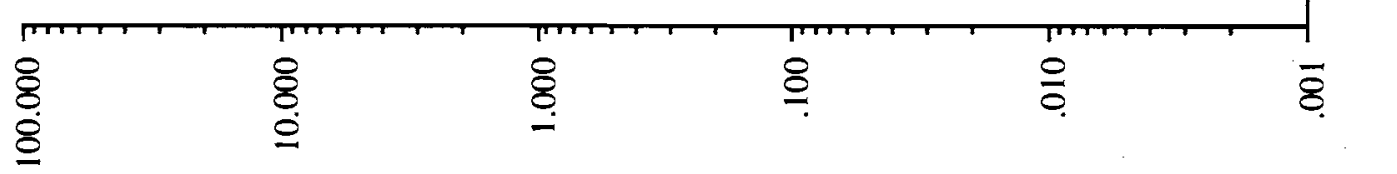

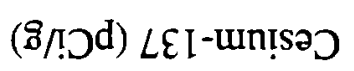


with sampling of B Pond. Samples were last collected from the 300 Area trenches in 1989 and from Gable Mountain Pond in 1986 at which times those sites were decommissioned as low-level aqueous waste sites, hence the data are incomplete for evaluating trends over the 10-year study period.

There were no apparent differences between ducks collected from the Columbia River at 100-N and from the background location at Vantage, Washington (see Figure 2.1), in 1990, indicating that the 100-N ducks were likely migrants.

\subsection{Upland Game Birds}

Cesium-137 has been most consistently sampled in upland game bird muscle fram the 100-D to 100-F Areas over the study period. Collections from the 200 Areas and 300 Area were generally incomplete because of low population density of game birds in those areas. Median concentrations hovered at the detection limit of 0.015 to $0.02 \mathrm{pCi} / \mathrm{g}$. Generally, concentrations of ${ }^{137} \mathrm{Cs}$ in upland game • birds collected in the 1980s from the 200 Areas was higher than other areas on Site (Figure 4.6).

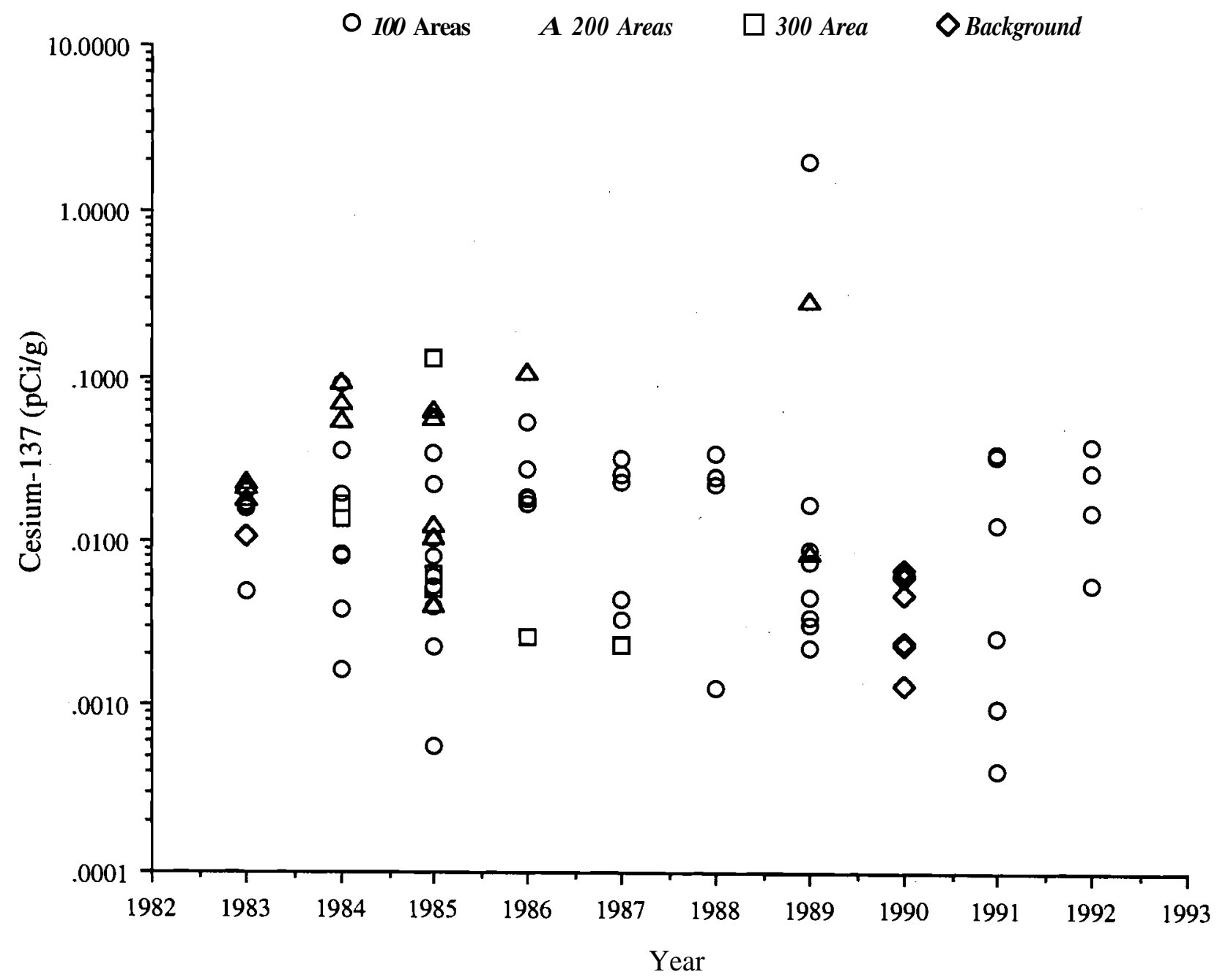

Figure 4.6. Cesium-137 in Upland Game Bird Muscle 


\subsection{Discussion}

Data collected for the wildlife monitoring program provide a good overview of radionuclide concentrations in wildlife found on the Hanford Site. While the data were at times erratic for individual species or in particular years, the coverage for the 10-year study period is extensive and broad. With the exception of ${ }^{137} \mathrm{Cs}$ concentrations in duck muscle samples collected from B Pond, and isolated samples of ${ }^{90} \mathrm{Sr}$ in rabbit or deer bones, there is little indication of elevated concentrations of either radionuclide in wildlife collected from the Hanford Site. Most measured concentrations are close to detectionlevels or comparable to concentrations found in wildlife collected from background locations.

One of the reasons concentrations of radionuclides in wildlife collected on the Hanford Site were close to background concentrations was the decommissioning of Hanford facilities and subsequent removal of waste disposal sites that are attractive to wildlife. Because of Hanford's arid climate, sources of drinking water are an attractant to wildlife. During the past 9 years, several low-level radiological waste ponds have been decommissioned including U Pond in 1985, Gable Mountain Pond in 1988, and the 300 Area Trenches in 1991. B Pond is scheduled for decommissioning in 1994. Potential contamination sources like the old 100-N Trench were modified to prevent access by wildlife. Open facilities in particular afforded more opportunity for wildlife exposure to radioactivity than did buried low-level waste disposal sites and cribs.

It is interesting to note that background samples of venison collected from Stevens County in northeastern Washington State had the highest concentrations of ${ }^{137} \mathrm{Cs}$ measured in deer during the 10 -year study period. Stevens County receives about three times the annual precipitation of Hanford and it is likely that the elevated concentrations are due to fallout from nuclear weapons testing. Additional background deer concentrations are needed to provide a better reference for comparison to Hanford Site deer.

\subsection{Offsite Movement of Wildlife and Potential Public Exposure}

A key issue at Hanford pertains to the potential for contaminated wildlife to move off the Site. This issue revolves about the potential for Site wildlife to be hunted and consumed by hunters after moving off Site. These concerns are more pertinent for deer and waterfowl. Rabbits are restricted to the Site because they can not cross the Columbia River and for those populations residing adjacent to industrialized areas, they are generally too isolated from the public to be hunted. Black-tailed jackrabbit home ranges may cover 16.2 to 20.2 ha (40 to 49.9 acre), i.e., a maximum circle of $0.5 \mathrm{~km}$ (0.3 mi) in diameter (Dunn et al. 1982). Cottontails have considerably smaller home ranges and use shelter provided by buildings, stored equipment, and building supplies (Chapman et al. 1982). Upland game birds may be hunted, but there is also the possibility that pheasants collected from the 100 Areas could have relocated there as a result of hunting pressure in Franklin or Grant Counties.

Deer movements on and off the Site have been monitored extensively in the past (Eberhardt et al. 1979; Eberhardt et al. 1982) and additional studies are ongoing (Cadwell 1994). Fawns tagged between 1969 through 1977 were found as far away as $113 \mathrm{~km}$ (70 mi) off Site. Eberhardt et al. (1982), using radiotelemetry, showed that Hanford Site deer migrated off Site where they could be harvested by hunters. In 1982, they estimated that about $8 \%$ ( 0 to $21 \%$ was the $95 \%$ confidence interval) of resident deer may have been harvested. Estimates of mean home range $( \pm 1$ standard deviation) for mule deer were $3900 \pm 2700$ ha $(9600 \pm 6700$ acres), equivalent to a circle with a diameter of $7 \mathrm{~km}$ (4.4 mi). 


\subsection{Dose Considerations}

The mobility of wildlife is a concern for potential human exposure when species that reside on Site can move off Site. The maximum dose (50-year Effective Dose Equivalent [EDE]) to humans from eating $1.0 \mathrm{~kg}(2.2 \mathrm{lb})$ of duck meat collected in 1992 containing the highest concentration of ${ }^{137} \mathrm{Cs}$ from B Pond (1.32 pCi $/ \mathrm{g})$ was $0.07 \mathrm{mrem}(0.0007 \mathrm{mSv})$. Dose estimatesfor deer and pheasant were proportionately lower (Table 5.1). A maximum dose estimate from earlier years can be estimated by multiplying the 1992 dose estimate by the ratio of the $1964{ }^{137} \mathrm{Cs}$ concentration to the $1992{ }^{137} \mathrm{Cs}$ concentrations in the table. Because B Pond ducks had the highest muscle concentrations of ${ }^{137} \mathrm{Cs}$ during the study period, this species represents the maximum source term for dose estimation purposes. For a point of reference, the annual EDE resulting from the presence of naturally occurring ${ }^{40} \mathrm{~K}$ in human tissue is $18 \mathrm{mrem} / \mathrm{yr}$ (Eisenbud 1987). Strontium-90 would not contribute to human dose from the consumption of wildlife because it does not accumulate in muscle which humans would consume from harvested wildlife.

The DOE guideline for public exposure, which is based on the National Council on Radiation Protection and Measurements' recommendations (NCRP 1987), is $100 \mathrm{mrem} / \mathrm{yr}$ (DOE 1990). Estimates of background radiation to humans from natural sources of radiation are approximately $300 \mathrm{mrem} / \mathrm{yr}$. The DOE field office is notified when a wildlife concentration reaches a level that would result in a 1.0mrem dose to a human consumer (DOE 1991). This 1.0-mrem dose would be attained from the consumption of $40 \mathrm{~kg}(88 \mathrm{lb})$ in one year of wildlife muscle that contained $0.54 \mathrm{pCi}{ }^{137} \mathrm{Cs} / \mathrm{g}$ of meat. This observation illustrates how significant low tissue concentrations are in Hanford Site wildlife and provides a measure of comparison for estimated doses resulting from the hypothetical consumption of Site wildlife collected at offsite locations. Concentrations of radioactivity measured in Site wildlife over the 10-year study period do not constitute a significant radiological dose to the hypothetical public consumer.

In a related study, recent monitoring of Hanford workers showed slightly elevated concentrations of ${ }^{137}$ Cs in some workers (MacLellan et al. 1993). Following interviews, these workers were subsequently characterized as big game hunters. After obtaining samples of game meat (deer, elk, moose, cougar, and bear) for analysis, it was determined that the source of the slightly elevated levels of ${ }^{137} \mathrm{Cs}$ body burdens in workers was elevated background ${ }^{137} \mathrm{Cs}$ in game. The game samples were harvested from areas distant from Hanford in Washington and other states including Idaho, Montana, Oregon, and Alaska. These game samples had ${ }^{137} \mathrm{Cs}$ concentrations exceeding levels routinely measured in Hanford Site deer populations. The source of ${ }^{137} \mathrm{Cs}$ in wildlife was fallout deposition from atmospheric weapons testing conducted in the 1950s and early 1960s. The modeled effective dose equivalent in these individuals was about $2.5 \mathrm{mrem} / \mathrm{yr}$. The irony of this study is that Hanford workers were getting a greater dose from consumption of wildlife harvested away from Hanford than they were getting from residing in the local area around Hanford. 
Table 5.1. Fifty-YearEffective Dose Equivalent Resulting from the Consumption of Wildlife Muscle Collected in 1992

\begin{tabular}{lcc} 
Species & $\begin{array}{c}137 \mathrm{Cs} \\
(\mathrm{pCi} / \mathrm{g})\end{array}$ & $\begin{array}{c}\text { Dose } \\
\text { (mrem }[\mathrm{mSv}])\end{array}$ \\
\cline { 1 - 3 } Mule Deer & 0.017 & $0.001(0.00001)$ \\
Duck & 1.3 & $0.07(0.0007)$ \\
Pheasant & 0.04 & $0.002(0.00002)$
\end{tabular}




\subsection{Conclusions}

This study indicates that objectives of the environmental surveillance program for wildlife have been met. Results indicate that wildlife residing near onsite nuclear facilities have accumulated low levels of radionuclides; however, the levels do not constitute a risk to the public. Decommissioningof surfacewater waste ponds has reduced opportunities for exposure of wildlife to radionuclides and this reduction has been supported by observations in the general reduction of ${ }^{137} \mathrm{Cs}$ in ducks and slight decreases in ${ }^{90} \mathrm{Sr}$ in bone samples from deer and rabbits. Otherwise, monitored concentrations of radionuclides in wildlife samples have remained near or below the detection limit for most radionuclides monitored.

Comparisons of 1992 data to concentrations collected in prior years suggest that the current risk to the public is low and that engineering and administrative controls placed on the management and operation of low-level waste sites at Hanford have been generally successful in keeping levels of radioactivity in wildlife low or at background levels during the study period. 


\subsection{References}

Antonio, E. J., T, M. Poston, and W. H. Rickard, Jr. 1993. Radiological Survey of Shoreline Vegetation from the Hanford Reach of the Columbia River, 1990-1992. PNL-8797, Pacific Northwest Laboratory, Richland, Washington.

Backman, G. E., and L. W. Roddy. 1965, Radiation Control of Accidentally Contaminated Seepage Ponds. RL-SA-15, General Electric Company, Hanford Atomic Products Operation, Richland, Washington.

Bisping, L. E. 1991. Environmental Surveillance Master Sampling Schedule. PNL-7619, Pacific Northwest Laboratory, Richland, Washington.

Cadwell, L. L. 1994. Wildlife Studies on the Hanford Site: 1993 Highlights Report. PNL-9380, Pacific Northwest Laboratory, Richland, Washington.

Chapman, J. A., J. G. Hockman, and W. R. Edwards. 1982. "Cottontails." In Wild Mammals of North America, eds., J. A. Chapman and G. A. Feldhamer, pp. 83-123, The John Hopkins University Press, Baltimore, Maryland.

Coughtrey, P. J., and M. C. Thome. 1983. Radionuclide Distribution and Transport in Terrestrial and Aquatic Ecosystems, A Critical Review of Data. Vol. 1 of 6, A. A. Balkema, Rotterdam, Netherlands.

DiGregorio, D., T. Kitching, and P. Van Voris. 1977. "Radionuclide Transfer in Terrestrial Animals." Health Phys. 34:3-31.

Dirkes, R. L. 1990. 1988 Hanford Riverbank Springs Characterization Report. PNL-7500, Pacific Northwest Laboratory, Richland, Washington.

Denham, D. H., R. L. Dirkes, R. W. Hanf, T. M. Poston, M. E. Thiede, and R. K. Woodruff. 1993. Phase I Summaries of Radionuclide Concentration Data for Vegetation, River Water, Drinking Water and Fish. PNWD-2145 HEDR, Battelle, Pacific Northwest Laboratories, Richland, Washington.

Dunn, J. P., J. A. Chapman, and R. E. Marsh. 1982. "Jackrabbits." In Wild Mammals of North America, eds., J. A. Chapman and G. A. Feldhamer, pp. 124-145. The John Hopkins University Press, Baltimore, Maryland.

Eberhardt, L. E., J. D. Hedlund, and W. H. Rickard. 1979. Tagging Studies of Mule Deer Fawns on the Hanford Site, 1969-1977. PNL-4420, Pacific Northwest Laboratory, Richland, Washington.

Eberhardt, L. E., E. E. Hanson, and L. L. Cadwell. 1982. Analysis of Radionuclide Concentrations and Movement Patterns of Hanford Site Mule Deer. PNL-4420, Pacific Northwest Laboratory, Richland, Washington.

Eisenbud,M. 1987. Environmental Radioactivity. 3rd Ed., Academic Press, New York

Emery, R. M., and M. C. McShane. 1978. Comparative Ecology of Nuclear Waste Ponds and Streams on the Hanford Site. PNL-2499, Pacific Northwest Laboratory, Richland, Washington. 
Fitzner, R. E. and W. H. Rickard. 1975. Avifauna of Waste Ponds, ERDA Hanford Reservation, Benton County, Washington. BNWL-1885, Pacific Northwest Laboratory, Richland, Washington.

Foster, R. F., and Environmental Studies and Evaluation Staff. 1965. Evaluation of Radiological Conditions in the Vicinity of Hanford for 1964. BNWL-90, Pacific Northwest Laboratory, Richland, Washington.

Foster, R. F., and EnvironmentalStudies and Evaluation Staff. 1966. Evaluation of Radiological Conditions in the Vicinity of Hanford for 1965. BNWL-316, Pacific Northwest Laboratory, Richland, Washington.

Hanf, R. W., R. L. Dirkes, and J. P. Duncan. 1992. Radionuclide Contaminationof Fish, Shellfish, and Waterfowl Exposed to Hanford Effluents: Annual Summaries, 1945-1972. PNWD-1986 HEDR, Battelle, Pacific Northwest Laboratories, Richland, Washington.

Heeb, C. M., and D. J. Bates. 1994. Radionuclide Releases to the Columbia River from Hanford Operations, 1944-1971. PNWD-2223 HEDR, Battelle, Pacific Northwest Laboratories, Richland, Washington.

Jaquish, R. E., and R. W. Bryce (eds). 1990. Hanford Site Environmental Report for Calendar Year 1989. PNL-6825, Pacific Northwest Laboratory, Richland, Washington.

Klepper, E. L., L. E. Rogers, J. D. Hedlund, and R,. G. Schreckhise. 1979. Radioactivity Associated with Biota and Soils of the 216-A-24 Crib. PNL-1948, Pacific Northwest Laboratory, Richland, Washington.

Landeen, D. S. A. R. Johnson, and R. M. Mitchell. 1992. Status of Birds at the Hanford Site in SoutheasternWashington. WHC-EP-0402, Westinghouse Hanford Company, Richland, Washington.

MacLellan, J. A., T. P. Lynch, G. A. Rieksts, and R. L. Brodzinski. 1993. "Identificationof Environmentally Derived Cesium-137 Burdens in a Worker Population." In Environmental Health Physics, Proceedings of the 26th Year Topical Meeting of the Health Physics Society, eds., R. L. Kathem., D. H. Denham, K. Salmon, and D. Felton, pp. 171-179. Research Enterprises, Inc., Richland, Washington.

McCormack, W. D., and J. M. V. Carlile. 1984. Investigation of Ground-Water Seepage from the Hanford Shoreline of the Columbia River. PNL-5289, Pacific Northwest Laboratory, Richland, Washington.

Miller, R. L., and R. K. Whalen. 1987. Estimates of Solid Waste Buried in 100 Area Burial Grounds. WHC-EP-0087, Westinghouse Hanford Company, Richland, Washington.

National Council on Radiation Protection and Measurements (NCRP) . 1987. Recommendations on Limits for Exposure to Ionizing Radiation. NCRP Report No. 91, National Council on Radiation Protection and Measurements, Bethesda, Maryland.

OFFarrell, T. P., R. E. Fitzner, and R. O. Gilbert. 1973. Distributionof Radioactive Jackrabbit Pellets in the Vicinity of the B-C Cribs, 200 East Area, U.S. A.E.C. Hanford Reservation. BNWL-1794, Pacific Northwest Laboratory, Richland, Washington. 
Poston, T. M., K. R. Price, and D. R. Newcomer. 1991. An Evaluation of the Chemical, Radiological, and Ecological Conditions of West Lake on the Hanford Site. PNL-7662, Pacific Northwest Laboratory, Richland, Washington.

Poston, T. M. 1994. Trends in Radionuclide Concentrationsin Hanford Reach Fish, 1982 through 1992. PNL-9960, Pacific Northwest Laboratory, Richland, Washington.

Rogers, L. E., and W. H. Rickard. 1977. Ecology of the 200 Area Plateau Waste Management Environs: A Status Report. PNL-2253, Pacific Northwest Laboratory, Richland, Washington.

U.S. Department of Energy (DOE). 1990. "Radiation Protection of the Public and the Environment." DOE Order 5400.5.

U.S. Department of Energy (DOE). 1991. Environmental Monitoring Plan. DOE/RL 91-50, U.S.Department of Energy, Richland, Washington.

Walters, W. H., R. L. Dirkes, and B. A. Napier. 1992. Literature and Data Review for the Surface-water Pathway: Columbia River and Adjacent Coastal Areas. PNWL-2034 HEDR, Battelle, Pacific Northwest Laboratories, Richland, Washington.

Woodruff, R. K., R. W. Hanf, and R. E. Lundgren (eds.). 1993. Hanford Site EnvironmentalReportfor Calendar Year 1992. PNL-8682, Pacific Northwest Laboratory, Richland, Washington. 


\section{Distribution}

No. of

Copies

\section{OFESITE}

2 Office of Scientific and Technical Information

2 Golder Associates 4104 148th Avenue N.E. Redmond, WA 98052

Attention: L. Swenson

Attention: W. Wright

S. F. Cross

Washington Department of Ecology

Mail Stop PV-11

Olympia, WA 98504-8711

Environmental Restoration/ Waste Mangement

Yakama Indian Nation

P.O. Box 151

Toppenish, WA 98948

Attention: R. Jim

3 Confederated Tribes of the Umatilla Indian Reservation P.O. Box 638

Pendleton, OR 97801

Attention: J. R. Wilkinson

Attention: A. Childs

Attention: R. George

Nez Perce Tribe

P.O. Box 365

Lapwai, ID 83540-0365

Attention: D. Powaukee

D. Teel

Washington State Department of Ecology

Nuclear Waste Program

P.O. Box 1386

Richland, WA 99352
No. of

Copies

J. Erickson

Washington State Department of Health

Division of Radiation

Protection

Airdustrial Center

Building 5, M.S. C-13

Olympia, WA 98503

\section{ONSITE}

11 DOE Richland Operations Office
R. F. Brich
A5-19
E. D. Goller
A5-19
J. B. Hall (5)
A5-55
R. D. Hildebrand
A $5-55$
H. P. Mooers
A5-55
B. A. Ward
A5-19
D. C. Ward
A5-55

2 US. Environmental Protection Agency
L. E. Gadbois
B5-01
P. S. Innes
B5-01

9 Westinghouse Hanford Company

L. P. Diediker

T1 -30

J. J. Dorian

H6-20

G. E. Fitzgibbon

H6-07

E. M. Greager

H6-20

A. R. Johnson

H6-20

K. J. Moss

$\mathrm{XO}-21$

C. J. Perkins

$\mathrm{XO}-21$

J. W. Schmidt

H6-20

Public Reading Room

2 Bechtel Hanford Inc.

K. G. Gano

XO-21

S. G. Weiss

H6-04 
No. of

Copies

58 Pacific Northwest Laboratory

\section{S. Abernethy}

E. J. Antonio

D. J. Bates

M. L. Blanton

C. A. Brandt

R. W. Bryce

L. L. Cadwell

A. T. Cooper

C. E. Cushing

D. D. Dauble

R. L. Dirkes

S. L. Friant

D. R. Geist

J. A. Hall

R. W. Hanf, Jr.

R. E. Jaquish

K. K. Large

R. E. Lundgren

E. W. Lusty

D. A. Mueller

D. A. Neitzel

G. W. Patton

T. M. Poston (20)

K. M. Probasco

J. K. Soldat

M. E. Thiede

B. L. Tiller

H. E. Westerdahl (3)

Publishing Coordination

SESP Historical Files/

R. L. Dirkes (2)

Technical Report Files (5)
No. of

Copies

Routing

R. M. Ecker

M. J. Graham

P. M. Irving

S. A. Rawson

P. C. Hays - last
Sequim

K6-78

K6-98

K6-81

K6-63

K6-96

K6-63

K6-61

K6-54

K6-54

K6-61

K6-52

K6-54

K6-63

K6-61

B1-34

K6-61

K6-62

K6-79

K6-79

K6-54

K6-61

K6-61

K6-52

K3-54

K6-52

K6-63

K6-60

K1-06

K6-61

K6-86 